\title{
CIDADANIA TRANSLOCAL: TECENDO POSSIBILIDADES
}

TRANSLOCAL CITIZENSHIP: weaving possibilities

CIUDADANÍA TRANSLOCAL: tramando posibilidades

João Martins Bertaso

1 Mestre e Doutor em Direito pela UFSC. Pós-doutorado pela UNISINOS. Professor pesquisador vinculado a Universidade Regional Integrada (URI) do Alto Uruguai e das Missões. Coordenador Acadêmico do Programa de Mestrado em Direito/URI. Desenvolve pesquisa em cidadania, direitos humanos e psicanálise. Coordenador do Grupo de Pesquisa: Novos Direitos na Sociedade Globalizada. 
Resumo: O texto analisa as condições de possibilidades de a cidadania como prática dos direitos humanos se tornar mediadora intercultural e potencializar o diálogo entre as culturas; concebe os direitos humanos como mecanismos forjados para proteção da humanidade, de proteção não restrita às fronteiras dos Estados nacionais; como mecanismos voltados a alavancar uma cultura fraterna de proteção local e global; a cidadania vinculada aos direitos humanos viabiliza a realização da pessoa na medida da dignidade humana; produz novas práticas sociais e implica reconhecimento, acolhimento e respeito ao direito do outro, dando sustentabilidade às sociedades multiculturais e viabiliza atores sociais solidários.

Palavras-chave: Cidadania. Interculturalidade. Direitos humanos.

Abstract: This paper analyzes the conditions of possibility of citizenship as a practice of human rights, as an intercultural mediator and enhancing dialogue between cultures; it understands human rights as mechanisms forged for the protection of humanity, of unrestricted protection of the borders of national States; as mechanisms aimed at leveraging a fraternal culture of local and global protection; citizenship linked to human rights enables the fulfillment of the person in terms of the human dignity; it produces new social practices and involves recognition, acceptance and respect for the rights of others, giving sustainability to multicultural societies and enabling solidary social actors.

Keywords: Citizenship. Interculturality. Human rights.

Resumen: El texto analiza las condiciones de posibilidad de que la ciudadanía como práctica de los derechos humanos se vuelva mediadora intercultural y potencie el diálogo entre las culturas; concibe los derechos humanos como mecanismos forjados para la protección de la humanidad, de protección no restringida a las fronteras de los Estados nacionales; como mecanismos dirigidos a impulsar una cultura fraterna de protección local y global; la ciudadanía vinculada a los derechos humanos permite la 
realización de la persona en la medida de la dignidad humana; produce nuevas prácticas sociales e implica reconocimiento, acogida y respeto al derecho del otro, dando sostenibilidad a las sociedades multiculturales y viabilizando actores sociales solidarios.

Palabras clave: Ciudadanía. Interculturalidad. Derechos humanos.

\section{INTRODUÇÃO}

ivemos em tempos de fuga dos lugares comuns que
compartimentalizaram os saberes às redomas teóricas e encouraçadas.
Os novos caminhares, como espaços epistêmicos de autonomia, sinalizam expandidos para os valores da democracia, da vivência fraterna e de uma consciência voltada a uma cultura de paz. São caminhos que podem (re)traçar linhas de contatos interculturais. Ao mesmo tempo são utopias que em seu conjunto, surpreendem o senso comum teórico, à medida que mostram a cartografia da diversidade das identidades culturais que emergem nesses novos cenários sociais, e que estão a demandar reconhecimento político e social igualitário.

Com base no marco das sociedades multiculturais, propomos para a economia da pesquisa, $^{2}$ da qual este ensaio resulta, uma reflexão da cidadania como realização da pessoa humana, com o propósito de transcender as fronteiras ideológicas e culturais que marcaram e ainda marcam a ideia de cidadania desde a modernidade. Um modelo de cidadania que não abarca a todos. A projeção de uma noção de cidadania de viés includente que possua características fraternas e interculturais passa, necessariamente, pelo diálogo como condição de possibilidades de um novo modo de se realizar as interações e os conviveres sustentáveis interculturais, e de reconhecimento do outro nas sociedades atuais. Nesse aspecto, projetamos uma concepção de cidadania que possa ter eficácia

2 Este ensaio resulta do Projeto de Pesquisa Cidadania e Interculturalidade, vinculado à Linha I, de Pesquisa do Programa de Mestrado em Direito da URI. O projeto subsidia a disciplina Direitos humanos e cidadania em sociedades multiculturais, do Curso de Mestrado em Direito da mesma IES. 
na prática dos direitos humanos, que ancore as condições de possibilidades da realização paritária para atender a diversidade socioétnicas, como é o caso da sociedade brasileira.

Por um lado, as dificuldades são dadas por ordem de uma envolvente linguagem que conformou a ideia de cidadania de modelo nacional, racionalizada que foi para dar conta de uma sociedade monocultural, na medida em que introduzia uma rede de significados partilhados, que tomaram sentidos de verdades desde o século XIX. Além de demarcarem uma espécie de geografia cultural, ${ }^{3}$ se expandem renovados no interior de um fenômeno globalizante de pretensões imperiais. Sabemos que as ideias não existem e nem progridem no vácuo. Elas se propagam no conjunto das relações sociais que as (re)produzem e as tangem da eficácia que possuem. Porém, apresentam graus de compreensões limitados quando a defasagem histórica se faz alargada, ou seja, quando os fenômenos nominados/conceituados são transladados literalmente de um período de tempo a outro sem as necessárias ressignificações.

De outro lado, em cenários dinâmicos como são os atuais, a cidadania vai sendo solicitada de maneira significativa nas mediações culturais. Sobretudo são cenários multiculturais nos quais a noção moderna de cidadania perde o sentido construído já no século XIX, dada à pretensão política e jurídica de operacionalizar a assimilação e o apagamento da diversidade das identidades étnico-sociais em benefício da formação de uma identidade para os EstadosNação. Tal pretensão política e ideológica fez crer ser possível a transformação das sociedades multiculturais e multiétnicas da época, em sociedades nacionais monoculturais. Surgiu desse contexto a convergência ou a sinonímia entre cidadania e identidade.

Sabe-se que no século XVIII a cidadania adveio com um cidadão de perfil mais romântico que cívico. A revolução iluminista e burguesa ensejou as liberdades individuais e públicas, a derrocada das hierarquias estamentais, mas permaneceu amarrada em seus contornos comunitários. E por ocasião dos movimentos da classe operária, no século XIX, a cidadania esteve envolvida com um conjunto de 3 PANIKKAR, Raimón. Paz e Interculturalidad: uma reflexión filosófica. Tradução de Germán Ancochea Soto. Milán: Herder, 2002. 
demandas específicas, momento em que surgia a cidadania operária e um cidadão produtor. No entanto, ao adentrar no século XX, as liberdades potencializaram a cidadania a lutar pela igualdade. Seguindo os princípios da Declaração francesa, a liberdade e a igualdade encontram abrigo no Estado nacional. ${ }^{4}$ A construção dos Estados nacionais se fez, assim, vinculada à expansão e à universalização dos direitos de uma comunidade de cidadãos livres e iguais. ${ }^{5}$ Nesse curso, ocorreu o reconhecimento e a subordinação da cidadania às leis estatais, dando o acabamento necessário a essa estrutura vincular entre um poder centralizado e soberano e a população de cidadãos que constituía a comunidade política.

Já no curso do século XX, ao transpor aos movimentos de classe e as cercanias territoriais, bem como os limites ideológicos que alçava o cidadão a identidade nacional, a cidadania passou a ser compreendida a partir de um conjunto de direitos fundamentais e de práticas sociais, para assegurar a realização do sujeito e da sua dignidade, independentemente do Estado de pertence do cidadão. Ou seja, pensamos cidadania a partir da ideia de que os homens todos, não só os cidadãos, são livres e iguais em dignidade e direitos.

Neste início de ensaio, cabe ressaltarmos que os conceitos de cidadania e de direitos humanos deflagraram um processo dialógico que convergiu a devires emancipatórios de várias dimensões e materialidades, que perpassa a linha dos tempos. Qual seja, em todos os momentos direitos humanos e cidadania potencializaram as lutas daqueles que demandam por justiça e que vivem em situações extremas de indignidade coletiva.

Em tempos atuais, a comunicação potencializa e expande as dimensões local/ global, os deslocamentos e as migrações humanas impactam fortemente sobre as estruturas dos Estados nacionais, desafiando nossa sensibilidade com relação a essa nova cartografia, que faz a dinâmica das práticas sociais. Esses novos

4 Cf, Declaração Francesa, 1789 [...] Art. 3.0 O princípio de toda a soberania reside, essencialmente, na nação. Nenhum corpo, nenhum indivíduo pode exercer autoridade que dela não emane expressamente.

5 Além da universalização como uma característica da cidadania moderna, outra característica de cidadania foi a territorialização que demarcou o espaço de abrangência do status; assim como a individualização do cidadão veio estabelecer os vínculos diretos entre o indivíduo e o Estado, eliminando as demais formas de tutela de parte de outros poderes sociais. Esse fato naturalizou a ideia de cidadania e identidade nacional, vinculando cidadania e identidade. 
contextos sinalizam para a forma multicultural da sociedade, que suscita o diálogo como meio de mediar as diferentes tendências que constitui o social, como é o caso dos conflitos religiosos, políticos, de gênero, de sexo, entre tantos outros, a fim de se surjam as condições de possibilidades aos diferentes conviveres no cotidiano complexo das inter-relações humanas. Nesse quadro de pluralismo social, pensamos no envolvimento da cidadania e dos direitos humanos no reconhecimento social e político, em um processo dialógico que possa dar conta de um conviver sustentável de todas as identidades que constituem e que forma diversidade da sociedade nacional.

Sucede que as complexas relações sociais atuais, os espaços de interações continuadas, locais e globais, não só aproximam pessoas e comunidades, mas também geram constantes estranhezas às múltiplas confrontações com o Outro; diferenças que permaneciam ocultadas, não enunciadas no processo hermenêutico oficial de assimilação e integração cultural nacional. Os novos fenômenos, próprios deste momento histórico, vão possibilitando, assim, a novos sujeitos individuais e coletivos que surgem envolvidos numa rede de cumplicidades, reconhecidos como referência central da política. ${ }^{6}$

Daí a pertinência de refletirmos cidadania e direitos humanos não dissociados. De conceber os direitos humanos como mecanismos forjados para proteção da humanidade e de proteção não restrita às fronteiras dos Estados nacionais; mecanismos voltados a alavancar uma cultura fraterna, de proteção local e global, sem radicalizações e universalizações desmedidas de seus valores. Essa vincularidade da Cidadania com os Direitos Humanos é posta em razão de uma relação mais fraterna, inclusiva e respeitosa aos direitos de todos, ${ }^{7}$ diferentemente do modelo idealizado para a cidadania nacional. ${ }^{8}$

6 Vivemos em tempos que "ditaduras podem ser derrubadas, pelas mãos desarmadas do povo, mesmo que essas mãos estivessem ensanguentadas pelo sacrifício dos que tombaram [...] Governos foram denunciados. A mídia se tornou suspeita. A confiança desvaneceu-se." In. CASTELLS, Manuel. Redes de Indignação e esperança: movimentos sociais na era da internet. Rio de Janeiro: Zahar, 2013.

7 WALLERSTEIN, Immanuel. O fim do mundo como o concebemos: ciência social para o século XXI. Trad. Renato Aguiar. Rio de Janeiro: Revan, 2002b. p. 53. Conforme compreendemos, numa sociedade globalizada e multicultural como a que se vive atualmente, a perda do sentido da concepção de cidadania tomada/enclausurada no discurso da identidade nacional, não significa o esgotamento da ideia da cidadania e de sua realização vinculada aos direitos humanos.

8 A cidadania de modelo nacional, como vimos, teria a pretensão de transmitir identidade ao 
Ressalta-se que se trata de superar a concepção juridicista de cidadania, concebida no âmbito do Estado Liberal de Direito, ou seja, de uma ideia legalista e de exclusividade da cidadania. Tal ideia dimensionou e ideologizou a construção das condições de negação do outro, do estrangeiro, por (des)equiparação. E, no nível interno, justificou a seletiva participação na vida política do Estado, impactando sobre o potencial político do cidadão, restringindo-o a capacidade de votar e de ser votado. Assim, por essa via, o Estado pode selecionar, na forma da lei, aqueles que poderiam exercer- os direitos políticos e participar do exercício do poder social instituído, dizendo diferente daqueles que poderiam desfrutar dos benefícios da vida comunitária. Porém, com a Declaração Universal dos Direitos do Homem e, em especial, com o advento dos novos direitos advindos fundamentalizados na Constituição Federal de 1988, não é mais possível, a partir dessa nova conformação política e jurídica, sustentar a ideia de cidadania, reduzida ao um viés assimilador monocultural. A partir de então, os Estados e a sua instrumentalidade instituída se transformaram em sujeitos de obrigação social, ${ }^{9}$ com a finalidade de manter, sustentar e promover, na medida da dignidade humana, todos os direitos de liberdade, de igualdade e as distinções asseguradas, viabilizando a realização da cidadania. 10

cidadão para funcionar na esfera internacional. A cidadania é status de natureza jurídicopolítica menos territorial que universal. O cidadão é um revestimento equipar-ativo de igualdade que simboliza o sujeito de direitos que também é uma ficção positivista que possibilita a pessoa agir de forma legitima e de legitimação ao sistema de dominação legal, no âmbito de um Estado de Direito.

9 Mesmo considerando sua abrangência semântica, faço uso da categoria Sujeito de Obrigação Social, ou "Estado de Obrigação Social", considerando aquelas obrigações próprias do Estado Social. Refiro-me modo especial, à burocracia galvanizada, que tem origem no poder do controle do tempo, traduzindo uma limitada consciência de sua função. Tal ideia de poder excessivo da autoridade burocrática ocultou/desidratou a consciência de obrigação para com a cidadania, que teve origem com o advento dos direitos sociais fundamentais. Tais direitos sociais se efetivam por meio de uma rede de serviços públicos e privados. Assim que a qualidade, a eficiência e a eficácia de tais serviços contam para a realização ou não da cidadania na sua dimensão social. Entre tantos outros, cito as injustificáveis demoras que se verificam, por exemplo, para a liberação de uma certidão de tempo de serviço público, as prolongadas filas/esperas para a obtenção de uma consulta ou acesso a um exame médico; o atendimento de um serviço de parte das empresas de telefonia e similares; a precariedade dos serviços de apoio à criança, ao idoso, ao portador de necessidades especiais, a todos os necessitados, e que repercute no plano real da vida da pessoa humana e da realização de direitos fundamentais de cidadania.

10 As condições de materialidade fática que requer a realização da cidadania resultam da efetivação de um conjunto de direitos e de obrigações fundamentais sociais (individuais e coletivas), sob a ótica da proporcionalidade e do equilíbrio que demandam os interesses individuais, coletivos e sociais. Trata-se de uma cidadania cujo sujeito/cidadão é concebido como um ser concreto, para além de uma abstração jurídica, para além de um ponto de 
Pensamos a cidadania com vincularidade nos Direitos Humanos. Um pouco do que fala Warat:11 "Os direitos do homem são direitos do outro homem [...] são os deveres do homem para com os outros homens. São também meus direitos frente aos outros". A partir de tais pressupostos referenciais, podemos pensar as relações intra e interpessoais de desenvolvimento humano e social digno. ${ }^{12}$

\section{TÓPICOS DE MULTICULTURALISMO E DIVERSIDADE CULTURAL}

Além dos povos originários indígenas, os portugueses e os africanos, e mais tarde o processo imigratório, determinaram a formação da diversidade cultural brasileira. Ainda que a diversidade caracterize nossa sociedade, no curso de nosso processo educacional não se construíram as condições necessárias para que o diálogo cultural pudesse se estabelecer. A diferença havia de ser saturada, apagada, assimilada para dar forma a uma identidade nacional única, monocultural. Uma construção amalgamada entre cidadania e identidade nacional. Desde o início o olhar verticalizado e seletivo sobre os segmentos humanos ensejaram as segregações e as discriminações, que grassou as formas de racismo, xenofobias, preconceitos e todas as demais hierarquizações sociais que se fazem realidade ainda hoje. Nesse cenário, a práxis colonialista foi o ponto "vélico" do processo social, político e jurídico que fez tradição na sociedade brasileira, modo especial, com relação aos afro-brasileiros e aos povos indígenas, na sua pluralidade. $O$ reconhecimento desse substrato colonialista remete à sociedade inteira da América Latina, ainda que essa dominação tenha impactado de maneira diferenciada em cada uma delas. ${ }^{13}$

A ênfase dada à igualdade fora baseada numa suposta ideia de construção de um projeto de identidade para a nação. Ainda que os propósitos fossem louváveis

convergência de normas, lembrando Hans Kelsen.

11 WARAT, Luis Alberto. O ofício do mediador. Florianópolis: Habitus, 2001. p. 172.

12 Toma-se a questão da dignidade humana como patamar de vida digna para todos, na perspectiva de acesso a um quantum de bens materiais. Também, é acolhida no sentido waratiano em que resulta de um viver com autonomia. E neste ensaio trabalha-se com a questão da autonomia, individual e coletiva, como sendo decorrente de uma sociedade que pratica os direitos humanos não agredindo a diversidade cultural das localidades.

13 Ver SAMPAIO \& ERTHAL (2006) entre outros. 
para a época, o que vimos foi a negação, o apagamento e a invisibilidade das diferenças, que foram justificados por meio de uma constelação de significados partilhados ideologicamente, com aspectos políticos, sociais e culturais. Partia-se de uma pré-compreensão de que de outra maneira não seria possível dar forma à justa igualização pretendida, pois, ao contrário, abalaria a implantação de um conjunto de valores e de símbolos, em torno dos quais se teceria a unificação e a assimilação das diferentes culturas. Assim, entramos no século XXI constituídos como Estado multicultural e multiétnico, mas ainda com os ranços de outrora. Questões de gênero, orientação sexual, religião e raça, entre outras, permanecem à mercê do devido reconhecimento social, político e cultural.

De outra parte, a diversidade cultural aponta para as condições de possibilidades de compreendermos esse fenômeno complexo que chamamos percepção da realidade, a realidade multicultural em que vivemos, bem como seus desafios, que vão se multiplicando em um mundo que oscila entre a unidade que tende à homogeinização, que vem na esteira da globalização, e a pluralidade de valores que implica respeito à alteridade, às diferenças e, consequentemente, à necessidade da interação entre as culturas, que têm demonstrado serem vitais para o convívio sustentável humano.

A tomada de consciência de que as sociedades que formam os estados da América do Sul possuem parâmetros de desigualdades, que levam a um estado de insustentabilidade social. Necessário se faz questionarmos a eficácia dos direitos de liberdade e o desejo de igualização social, em sociedades que não praticam a fraternidade em suas práticas sociais e institucionais. Referimo-nos às liberdades como direito de todos e à igualdade como finalidade a ser alcançada, para que possamos reverter as tendências de acumulação desmedida de alguns grupos, e a intolerância de outros, aos pobres e aos diferentes num prazo de tempo aceitável. ${ }^{14}$

Nesse sentido, o que chamamos de interculturalidade, remete às possibilidades da interação entre os mais diferentes grupos étnicoculturais, e às condições de

14 A Declaração Universal da UNESCO sobre a Diversidade Cultural, aprovada por 185 Estados-Membros em 2001, representa o primeiro instrumento de definição de padrão internacional destinado a preservar e promover a diversidade cultural e o diálogo intercultural. 
possibilidades de mediações e convívios, que se viabilizam a partir de relações baseadas no diálogo como mecanismo de entendimento e de respeito recíproco, uma vez que todas as culturas são merecedoras do igual reconhecimento, não depreciativo, justificado em suas diferenças.

O reconhecimento da complexa diversidade humana, visualizados a partir de valores e bens democráticos e humanitários, tendem ao proveito comum, ainda que não se atinja um consenso do que seja civilidade, na perspectiva mesmo da sustentabilidade do conjunto da sociedade humana.

Sabemos que as reflexões sobre o multiculturalismo implica compreender o tensionamento que as demandas provocam; o aprofundamento das aproximações possíveis que a temática remete e o atendimento impostergável da agenda social contemporânea que cartografa as sociedades em suas pluralidades, modo especial, das americanas do sul. O papel central que a cultura desempenha atualmente no processo social não a faz absorver toda a realidade, mas compreendêla constituinte da dinâmica própria das relações sociais, da imperiosidade do diálogo e do reconhecimento da diversidade cultural humana, assim como indica Santos, ${ }^{15}$ no reconhecer ao Outro, elevando-o à condição de sujeito.

Além dos fenômenos que envolvem sobremaneira a questão das imigrações, que têm desencadeado novos conflitos decorrentes de demandas por reconhecimento de direitos culturais, étnicos e identitários, se acentuam na América do Sul as demandas por reconhecimento de grupos minoritários nacionais e de povos originários. E ainda que sejam demandas que ocorrem na maioria dos países, se constituem como demandas próprias dos estados multiculturais, que segundo Kymlicka, ${ }^{16}$ possuem em suas estruturas sociais minorias que demandam por direitos étnicos, de autogoverno, no caso dos povos originários, de não terem suas terras invadidas e exploradas pelo homem "branco", agentes de um modelo depredador dos meios ambiental e cultural. Motivos suficientes do reconhecimento de seus direitos de não serem expulsos de suas localidades. De outra parte demandam acesso paritário na composição da representação democrática, no conjunto dos 15 SANTOS, Boaventura de Souza. Reconhecer para libertar: os caminhos do cosmopolitismo multicultural. Rio de Janeiro: Civilização Brasiliense, 2003.

16 KYMLICKA, Will. Ciudadanía Multicultural: uma teoria liberal de los derechos de las minrías. Barcelona: Paidós, 1996. 
meios instituídos da sociedade nacional. São alguns dos fatores que remetem a problemática das minorias ao devido reconhecimento na ordem política do conjunto da sociedade da qual fazem parte.

As reflexões sobre sociedades multiculturais implicam reconhecer os modos pelos quais se manejam as diferenças nessa interação social. Porém isto é ainda pouco para se compreender a dimensão e os significados do multiculturalismo. $O$ multiculturalismo remete não apenas a um discurso em defesa da diversidade de formas de vida existentes nas sociedades contemporâneas, mas a um conjunto de aspectos fortemente vinculados entre si que expressam um fenômeno tensional e conflituoso e, sobre o aspecto da tensão, se verifica, entre outros tantos, o reconhecimento dos danos e das injustiças causados pela invisibilidade étnica e cultural desses grupos comunitários vulneráveis e hipossuficientes.

O reconhecimento da interação dos diferentes grupos que carregam e defendem as diferenças socioculturais supera, assim, o modelo hegemônico construído a partir do nation-building, sejam elas assimilacionistas ou diferencialistas, ou seja, atendendo políticas restritivas e purificadoras culturais ou por via daquelas promovedoras de desenvolvimentos separados. Da mesma forma, a fuga da tradição dominante nos países ocidentais, no caso de ontem, o liberalismo e, atualmente, o neoliberalismo, seus efeitos integrativos e assimilacionistas, modo especial, visam atender as demandas por inclusão, respeitando a pluralidade, tanto na forma de pensar e reivindicar a paridade na interação quanto nas práticas institucionais. Nesse aspecto é básico o direcionamento das políticas públicas para alcançar e proteger a diversidade e a pluralidade dessas identidades e dessas culturas. ${ }^{17}$

Ainda mais, há que se considerar que a crescente sensibilidade para com o tema da diferença e da sua articulação em termos socioculturais, sob a forma de uma reivindicação de direitos para grupos subordinados, se liga a um descentramento da cultura ocidental que assume duas modalidades paradoxais. De um lado, por intermédio da matriz colonialista e imperialista que se difundiu mundo afora entre os séculos XVI e século XX, levando com ela modelos de

17 BERTASO, João Martins (Org.). Cidadania, diversidade e reconhecimento. 2. ed. Santo Ângelo: EDIURI, 2012. In: Introdução. 
organização social, desenvolvimento e mudança política que, em larga medida, se institucionalizaram no atual sistema de estados nacionais e numa economia mundial de viés capitalista. Essas práticas, esses valores e essas instituições historicamente foram construídos a partir da modernidade europeia e norteamericana, e se espalharam pelo mundo tornando-se modelo hegemônico de emancipação; também se impuseram onde a resistência se fez mostrar. Uma complexa composição de agentes rurais e urbanos encarregou-se de dobrar a resistência, forjando uma uniformidade que atendia pelo apelo da Nação, construindo um lugar ideal no "mundo moderno", atribuiu lugares aos que se posicionavam - contra ou a favor - frente às formas concretas de implementação destes projetos de modernizações. Este descentramento do Ocidente que carrega o modelo do estado nacional e a trajetória da modernização representa o grau zero das disputas multiculturais contemporâneas.

Quanto ao aspecto mais estreito e particularizado, o que se refere às imigrações, a tensão gira em torno das possíveis acomodações das minorias bem como de suas diferenças étnicas e raciais, frente às imposições da sociedade majoritária ou dominante. Já com relação aos povos originários e às minorias nacionais, como grassa no Brasil, o conflito gira em torno do meio natural (seus territórios) e do meio cultural, seus valores e suas práticas sociais, que são violados de diversas formas, modo especial, nos últimos vinte anos, pelo avanço, dentre outros meios predadores, do agronegócio e da sua forma de conquistar novas fronteiras para a produção de cereais, carne e madeira.

A lógica do argumento defendido no presente ensaio reside numa compreensão do multiculturalismo e dos pleitos das minorias a partir de uma dicotomia estabelecida entre movimento e institucionalização, entre pontos de instabilidade e busca de equilíbrio, entre distribuição justa de recursos e bens e o igual reconhecimento de todas e de cada uma das diferenças étnicas e culturais que fazem nossa sociedade multicultural. Entre as condições de possibilidades de compreensão da sociedade brasileira, implica pensar uma cidadania que possa abarcar a realização do cidadão numa interação intercultural. Aspecto que pode ser considerado como construção simbólico-política de grupos portadores de 
uma nova visão social, de um novo entusiasmo vital e de uma nova proposta emancipadora, como um caminho de fuga da naturalização da dominação, pela qual grupos hegemônicos impuseram e impõem às minorias, em especial, no decorrer da formação da geocultura da Modernidade, lembrando Wallenstein. ${ }^{18}$

O que pretendemos refletir a partir deste olhar são as emancipações de minorias socioétnicas, pois demandam o reconhecimento social e político que lhes garante o direito constituído. Essas referências normativas não foram e continuam não sendo suficientes para o encaminhamento e a garantia das práticas das liberdades necessárias e oportunizadoras da paridade e do igual acesso aos bens, aos serviços e às oportunidades de todos e de cada um desses grupos humanos vulneráveis, que fazem a existência ou a desejada configuração igualitárias concreta no conjunto da sociedade política. As situações conflituosas e instáveis que nascem dos movimentos de emancipação são de natureza convulsiva que não Ihes garante permanência, motivo pelo qual carecem de institucionalização e de políticas públicas continuadas. Além dessa vontade política constante, falta-lhes, sobretudo, representatividade, de diferentes graus, nas diferentes instâncias dos poderes constituídos.

Outro aspecto reside, em boa medida, nas práticas sociojurídicas que (re) alimentam o imaginário decorrente do modelo europeu conquistador, que resulta fortalecido na educação oficial que possuímos. As práticas sociais e institucionais que reconhecem a igual liberdade e a paridade na integração social, inobstante a relevância histórica, o lugar de importância desses grupos nos processos de construção de uma cultura dada ao respeito à diferença, à diversidade e à pluralidade, são ainda frágeis e insuficientes para a superação dos modelos ideológicos que naturalizaram a dominação no cotidiano brasileiro. As demandas desses grupos não possuem a potencialidade de definir, por elas próprias, com a eficácia de modificar os espaços normativos, as práticas de liberdade, nem tampouco suas garantias.

De parte a parte, há que se considerar a complementaridade que ocorre na relação necessária entre os movimentos e a institucionalização, entre lutas sociais 18 WALLERSTEIN, Immanuel. $\mathbf{O}$ fim do mundo como o concebemos: ciência social para o século XXI. Trad. Renato Aguiar. Rio de Janeiro: Revan, 2002b. 
como antecedentes e direitos como consequente, repercutindo na emancipação paritária de todos que criaram e criam as demandas ditas multiculturais ou minoritárias, pois elas, as demandas étnicas, identitárias e culturais, vêm aumentando significativamente.

Destacamos assim a relevância da parceria dos movimentos sociais e do Direito. Os movimentos sociais e políticos têm funcionado como pré-fontes dos direitos, e sua importância precede, na ação social, à garantia de permanência dos avanços civilizacionais, que de sua continuidade decorrem. Neste aspecto, os constituintes brasileiros foram sensíveis às demandas de reconhecimento que postulavam as minorias vulneráveis e hipossuficientes, por ocasião da elaboração do texto constitucional de 1988.

A filosofia do multiculturalismo percebe a sociedade não homogeneizada culturalmente, modo especial, quando esta homogeneidade se faz como medida para viabilizar um segmento branco e hegemônico. Nesse aspecto o multiculturalismo visa promover a emancipação de todos e cada uma da socioetnicidade pela qual é constituída uma sociedade de dimensões e características como a brasileira. Verifica-se que "cidadania e os direitos humanos se enlaçam na diversidade sociocultural que as constituem",19 e demandam reconhecimento e condições paritárias na interação social instituída, para que todos os cidadãos e os grupos que compõem a sociedade possam realizar-se a partir de um patamar aceitável de dignidade.

\section{PRESSUPOSTOS DE REALIZAÇÃO DE UMA CIDADANIA} INTERCULTURAL

Os direitos humanos têm evoluído consideravelmente nos últimos três séculos. Por um lado, as condições e as possibilidades históricas foram determinantes e, por outro, pelo fato de estarem vinculados aos movimentos humanos emancipatórios 19 BERTASO, J.M.; COPETTI SANTOS, A.L. Cidadania e direitos Culturais: a tutela judicial das minorias e hipossuficientes no Brasil. Santo Ângelo: Editora Ediuri, 2014. "Nossos vínculos jurídico-políticos se estabelecem com um Estado Constitucional e nossas identidades possuem vínculos com comunidades de crenças, como são as comunidades religiosas, étnicas e culturais, no caso das minorias em que as identidades são mais densas, pelas particularidades afins, que fazem vivas aquelas práticas referidas". Op. cit., p. 27. 
que ocorreram e ocorrem descontinuados no tempo. Seus protagonistas têm sido segmentos humanos oprimidos e/ou espoliados que a duras penas conquistam fragmentos materiais de igualdade e de liberdade, fragmentos que são albergados nos princípios e nas regras do Direito. Por se tratar de um processo libertário contra todas as formas de opressão sobre as dimensões do humano, funcionam, ressaltamos, como um discurso libertário contínuo na linha do tempo.

Em diferentes graus de efetividade e de eficácia, a fundamentalização dos direitos humanos pelos Estados contemporâneos tem se constituído em arcabouço de proteção e de promoção por meio desses mecanismos, repercutindo sobre as maiorias marginalizadas e excluídas quanto nas minorias étnicas e culturais vulneráveis, muitas vezes desconsideradas socialmente, em especial quando atingem um estado de sofrimento e de miserabilidade inaceitável aos olhos humanos. Afirma-se, assim, que direitos humanos e cidadania convergem e produzem sinergias, impactando sobre as práticas sociais, em diferentes níveis e intensidades. De outra parte, os direitos humanos e a cidadania funcionam num movimento pendular irradiando potências diversas, que transpassa a pessoa como tal. Nessa medida, sempre que uma estrutura de poder e força se fizer continuada e desproporcional sobre pessoas e ou grupos de pessoas, buscamos o amparo nos direitos humanos.

Dentre as várias funções que possuem os direitos humanos, Costa Douzinas destaca que, i) existe uma luta permanente por libertação e autonomia humana, e ii) o propósito de estabelecer limite (de regrar) os poderes sociais (públicos e privados). ${ }^{20} \mathrm{~A}$ partir desse olhar, podemos compreender os direitos humanos como criações do ideário iluminista e como criador da modernidade jurídica. Além desse duplo sentido, e de viabilizarem as liberdades, a igualdade e o respeito às diferenças, os direitos humanos são estratégicos para o funcionamento da sociedade política democrática, pois num só tempo, nas palavras de Douzinas, "institucionalizaram a ética da alteridade e o dever de respeitar a existência singular e única do Outro". ${ }^{21}$

Os direitos humanos possuem, assim, em sua genética, um duplo exponencial: "uma potência para resistir à onipotência do Estado; e um limite à capacidade 20 DOUZINAS, Costa. 0 fim dos direitos humanos. São Leopoldo: Unisinos, 2009.

21 DOUZINAS. Op. cit., p. 362. 
dos poderes sociais instituídos de negar a capacidade dos indivíduos, em cujo nome eles passaram a existir". 22 Assim os direitos humanos se forjaram como instrumentos de defesa da pessoa humana contra os poderes sociais, públicos e privados, os quais possuem a tendência de se tornarem poderes construtores de ações continuadas de opressão e de dominação.

No âmbito das sociedades complexas e globalizadas as mudanças se fazem apressadas. O que antes era possível delimitar e ordenar, com a intensificação desses fenômenos já não é mais. As fronteiras se relativizam, a comunicação e as informações passam a se dar em tempo real. Do mesmo modo, os problemas que antes eram possíveis de serem restritos ao âmbito territorial do Estado, hoje se tornam locais/globais. Nesses cenários se faz importante o respeito ao Outro, ao diferente. Em um mundo no qual se verifica uma interconexão entre as relações transculturais, para que se consiga uma cidadania efetiva e fortalecida por meio dos movimentos sociais, há que se reconhecer as diferenças sem submetê-las a hierarquizações. Dessa forma, a cidadania enseja a realização de todos em bases da dignidade humana.

Conforme podemos compreender, para que ocorram as condições de ressignificar a cidadania, retomando seu viés emancipatório além-fronteiras, há que se introduzir em seus genes ingredientes de fraternidade e de reconhecimento para que resulte modificada de sua natureza excludente e se potencialize de novas sensibilidades, condição necessária para reconhecer o Outro (estrangeiro/ deferente).

A ideia de uma cidadania solidária, respeitosa à diversidade cultural, às diferenças e afeita ao diálogo intercultural, é pressuposto de sua permanência como status protetivo das sociedades de cidadãos, e legitimadora dos governos democráticos em que quer que se formem sociedades humanas. Ou seja, tratase de reconhecer a universalidade da ideia de cidadania, não mais como um ingrediente de integração de "nós" e da exclusão do "outro", mas em dar as condições políticas e jurídicas que fazem as possibilidades de a pessoa humana construir-se no cotidiano de suas práticas sociais como transeunte visitante e/ou 
residente. Esse esboço de uma nova cidadania é adequado às lutas emancipatórias que marcarão a legitimidade dos governos democráticos no século XXI, para que possamos avançar no processo civilizacional.

Se o reconhecimento em nível pragmático das práticas sociais se dá pela diferença de certos valores que pessoas ou grupos possuem na perspectiva do reconhecimento político e social, então se dinamiza a renovação constante do direito no horizonte normativo de uma sociedade. Importa que a fraternidade seja tomada a partir da noção de responsabilidade e de cuidados de todos e de cada um. De fato, a fraternidade seria o reconhecimento social da singularidade individual ou grupal por oposição à igualdade generalizável (apanágio do direito). Desse modo, podemos compreender a cidadania como uma realização da pessoa humana.

Resta ampliado, assim, o núcleo genético conceitual da ideia de cidadania. ${ }^{23}$ Sua dimensão normativa permanece fundamental, constituindo as garantias constitucionais como um arcabouço ético-político que envolve os padrões desejados de condutas numa sociedade de cidadãos. Esse arcabouço tende angariar sua legitimidade pelos direitos humanos, pela fraternidade e pelos valores da democracia. Suas garantias proporcionam a incorporação dos avanços sociais que resulta do diálogo social em todas as suas formas.

Já sua dimensão política, além de potencializar o exercício dos direitos básicos numa sociedade republicana e democrática de iguais, encontra-se radicalmente associada às lutas sociais por reconhecimento. Decorre do desejo de indivíduos e de grupos de serem reconhecidos socialmente como iguais ou diferentes. Por outro lado, funciona como um conjunto de condições de lutas sociais daqueles que estão excluídos do sistema social e econômico, com seus impactos sobre os pertences, as proteções e as promoções da cultura. Um potencial/poder que está para garantia efetiva de reconhecimento e de inclusão (redistribuição da riqueza e do reconhecimento social). Essa é a dimensão de cidadania que cobre o cidadão de um potencial de poder político real. Trata-se de reconhecer o diálogo social continuado no cotidiano da vida, que daria as condições possíveis da redistribuição dos fluxos de poderes e riquezas a todos. Afirmada tal hipótese,

23 Para um maior aprofundamento, ver minha tese de doutoramento: Cidadania em direitos humanos em trânsito para a solidariedade (UFSC: 2004). 
teria repercussão forte sobre a função normativa dos direitos, qual seja, o de criar, manter, distribuir e redistribuir as condições e os serviços sociais, colocando à disposição da sociedade os meios materiais que programam as condições fáticas para sua efetiva realização.

A dimensão de reconhecimento agregada às genes da cidadania emana tanto do núcleo normativo quanto do político. Vincula-se às demandas por igualdade e por diferença: reconhecimento das demandas que envolvem distribuição e redistribuição materiais quanto daquelas de ordem simbólica que demandam reconhecimento dos direitos culturais de indivíduos e de comunidades (demandas simbólicas). Considera o reconhecimento coletivo, de onde surge a consciência do sujeito (autoconfiança, autorrespeito e autoestima) na perspectiva de Axel Honneth.

Quanto à fraternidade, engloba tanto a ideia de responsabilidade social para com o Outro quanto para com a humanidade em todos os seus aspectos. É reconhecida de valores comuns defendidos local/global. São valores considerados como uma dimensão dos direitos humanos em sua diversidade, no caso, o respeito aos direitos de igualdade e o respeito às diferenças, na perspectiva da construção de uma cultura de paz. A fraternidade se reconhece de uma dimensão cultural e de um comportamento ético.

Desse olhar, a cidadania em trânsito para um estado de solidariedade social, ambiental e de interações humanas que se sustentam pelo reconhecimento da diversidade cultural viria a potencializar a dignidade a cada grupo e a cada indivíduo, repercutindo a dignidade na medida da equiparação igualitária humana; a solidariedade como relação recíproca de cuidados entre iguais e diferentes, de onde é possível tecer fragmentos de amor a partir dos diversos modos humanos de relacionar-se.

A responsabilidade para com o outro e o reconhecimento da diversidade que compõe os indivíduos e as comunidades humanas formam um conjunto de ingredientes teóricos que, articulados de forma não dissociados, funcionam para potencializar um pensar novo a respeito da cidadania. Trata-se de categorias que retomariam a força semântica da concepção de cidadania, vinculando-a, desse modo, à pessoa humana nas suas múltiplas formas de viver a vida. 


\section{CONSIDERAÇÕES FINAIS}

Consideramos que, articulados, os ingredientes políticos, jurídicos e sociais, favorecem uma melhor compreensão do espaço teórico analisado, sabendo que sobram importantes questionamentos a serem feitos. Ressaltamos ainda a projeção utópica/emancipatória deste ensaio, que enfocou a cidadania de forma não dogmatizada, menos ainda com seus significados que perderam sua dimensão semântica, mas como devir na dinâmica do tempo.

1. A proposta é a de viabilizar a cidadania como categoria reflexiva, dinâmica e aberta às práticas dos direitos humanos e em proteção de todas as formas de vida que ligam o humano aos seus pertenceres;

2. A abordagem articulada e não dissociada do conceito de cidadania com a categorias de reconhecimento e a fraternidade viabiliza a prática dos direitos humanos, adequando-se à formação de novos contornos para abrigar o conceito de um devir-cidadania translocal;

3. Essa ideia de cidadania parte do pressuposto básico de que a realização de uma sociedade de homens e de mulheres livres e iguais está a exigir certo grau de fraternidade, para que a convivência se torne sustentável entre os diferentes grupos humanos. No nível epistêmico, verificamos a possibilidade da aproximação desses conceitos, porque não existem contradições teóricas entre cidadania, reconhecimento, direitos humanos e autonomia do sujeito. Desde essa base, o reconhecimento, a cidadania e os direitos humanos se vinculam sinergicamente e se expressam por meio de um cidadão que vai se constituindo em protagonista de um processo dialógico público;

4. Consideramos, assim, que as sociedades estão se tornando cada vez mais multiculturais, e por esse motivo propugnamos pelo diálogo como forma/meio de estabelecer um convívio sustentável entre as culturas, em nível local como global;

5. Consideramos ainda ser viável a realização da cidadania como prática dos direitos humanos, isto é, quando os direitos humanos forem utilizados no 
cotidiano, como mecanismos humanos de proteção e de promoção de todos, incluídas as dimensões cultural e ambiental;

6. Na medida em que a cidadania e os direitos humanos se viabilizam como mediadores interculturais, abrem-se às diferenças, à tolerância e ao reconhecimento do Outro;

7. Da maneira que entendemos cidadania e direitos humanos, essas categorias se revigoram pelo reconhecimento e pela fraternidade, formando complementaridade e se potencializam mutuamente. Articulam-se em solidariedade a uma forma sustentável de (con)vivência social, no âmbito das sociedades multiculturais no século XXI;

Resumindo: A realização da cidadania sustenta-se em três eixos congruentes: i) a legitimidade da ação que provém da prática dos direitos humanos incidindo sobre a organização da sociedade; ii) pela participação do sujeito na forma de cidadão/ator, interferindo na história individual e coletiva de sua(s) vida(s), modo que faz o trânsito de um cidadão com excessos de representação para o de protagonista social que implica nova modalidade participativa política/ cívica/solidária); e iii) pelo conhecimento e pelo reconhecimento do Outro na pluralidade do mundo social, ambiental e cultural, num processo de reflexão e diálogo intragrupal, intergrupal e transcultural.

A cidadania assim afirmada para as sociedades multiculturais traz uma ferramenta básica sem a qual se torna ineficiente no campo conceitual e ineficaz no plano pragmático, qual seja, o diálogo. O diálogo como possibilidade de convivência vai além da pretensão política e social que fez a antropologia do contrato social rousseauneano. A ideia de a cidadania vir a viabilizar o diálogo intercultural, nesta compreensão, é ontológica, pois, juntamente com aquelas categorias agregadas em seu conceito, o diálogo é aqui tomado como uma espécie de celebração com o Outro, na perspectiva do conhecimento e do reconhecimento, os quais se consideram os vínculos, os complementos, as sinergias e as revelações que esses (des)encontros proporcionam. 


\section{REFERÊNCIAS}

BAUMAN, Zygmunt. O mal-estar da pós-modernidade. Rio de Janeiro: Jorge Zahar, 1998.

BEDIN, Gilmar Antonio. A sociedade internacional e o século XXI: em busca da construção de uma ordem mundial justa e solidária. Ijuí: UNIJUÍ, 2001.

BERTASO, João Martins (org.). Cidadania, diversidade e reconhecimento. 2. ed. Santo Ângelo: EDIURI, 2012.

BERTASO, J.M.; COPETTI SANTOS, A.L. Cidadania e direitos Culturais: a tutela judicial das minorias e hipossuficientes no Brasil. Santo Ângelo: Editora Ediuri, 2014.

BERTASO, J.M. Cidadania e direitos humanos: um trânsito para a solidariedade. Tese de doutoramento. Florianópolis. UFSC, 2004.

BOBBIO, Norberto. A era dos direitos. 13ª tiragem. Rio de Janeiro: Campus, 1992.

CANCLINI, Néstor Garcia. Diferentes, desiguais e desconectados: mapas da interculturalidade. Trad. Luiz Sérgio Henrique. 3. ed. Rio de Janeiro: Editora UFRJ, 2009.

CAPELLA, Juan Ramón. Os cidadãos servos. Porto Alegre: Sérgio Antonio Fabris, 1998.

CAPRA, Fritjof. A Teia da Vida: uma nova compreensão científica dos sistemas vivos. Tradução de Newton Roberval Eichemberg. São Paulo: Cultrix, 1996.

CASTELLS, Manuel. A era da informação: economia, sociedade e cultura. Volume I: A sociedade em rede. 7. ed. rev. e ampl. Paz e Terra, 2003.

CASTELLS, Manuel. Redes de Indignação e esperança: movimentos sociais na era da internet. Rio de Janeiro: Zahar, 2013

DAL RI JÚNIOR, Arno. Evolução histórica e fundamentos politico-jurídicos da cidadania. In: DAL RI JÚNIOR, Arno; OLIVEIRA, Odete Maria de et al. (Orgs.) Cidadania e nacionalidade: efeitos e perspectivas: nacionais - regionais - globais. Ijuí: Unijuí, 2002.

DAL RI JUNIOR, Arno; OLIVEIRA, Odete Maria de (Orgs.). Relações Internacionais: interdependência e sociedade global. Ijuí: Unijuí, 2003.

DOUZINAS, Costa. O fim dos direitos humanos. São Leopoldo: Unisinos, 2009.

KRISTEVA, Julia. Estrangeiros para nós mesmos. Rio de Janeiro: Rocco, 1994. 
LOPES, Ana Maria D’Ávila. Da coexistência à convivência com o outro: entre o multiculturalismo e a interculturalidade. Rev. Inter. Mob. Hum, Brasília, Ano XX, No 38, jan./ jun. 2012.

MARSHAL, T. H. Cidadania, classe social e status. Rio de Janeiro: Zahar, 1967.

PANIKKAR, Raimón. Paz e Interculturalidad: uma reflexión filosófica. Tradução de Germán Ancochea Soto. Milán: Herder, 2002.

SANTOS, Boaventura de Souza. Reconhecer para libertar: os caminhos do cosmopolitismo multicultural. Rio de Janeiro: Civilização Brasiliense, 2003.

SANTOS, Milton. Por uma outra globalização: do pensamento único à consciência universal. 6. ed. Rio de Janeiro: Record, 2001.

SILVA, Geraldo Eulálio do Nascimento e; ACCIOLY, Hildebrando. Manual de direito internacional público. 15. ed. rev. e atual. por Paulo Borba Casella. São Paulo: Saraiva, 2002.

Site da Associação Brasileira de Organizações não Governamentais - ABONG: http:// abong.org.br/ongs.php.

SOUZA, Jessé. A construção social da subcidadania: Para uma sociologia política da modernidade periférica. Belo Horizonte: UFMG; Rio de Janeiro: IUPERJ, 2003.

TAYLOR, Charles. A política do reconhecimento. In: [et al.] Multiculturalismo: examinando a política de reconhecimento. Lisboa: Instituto Piaget, 1994, p. 45-94.

TOURAINE, Alain. Pensar outramente: o discurso interpretativo dominante. Tradução de Francisco Morás. Petrópolis, RJ: Vozes, 2009.

WALLERSTEIN, Immanuel. 0 fim do mundo como o concebemos: ciência social para o século XXI. Trad. Renato Aguiar. Rio de Janeiro: Revan, 2002b.

WARAT, Luis Alberto. O ofício do mediador. Florianópolis: Habitus, 2001.

WARAT, Luis Alberto. A Rua Grita Dionísio! Direitos Humanos da Alteridade, Surrealismo e Cartografia. Trad. e org. Vívian Alves de Assis, Júlio Cesar Marcellino Jr. e Alexandre Morais da Rosa. Rio de Janeiro: Lumen Juris, 2010. 